\title{
STRUCTURE AND HISTOLOGY OF EXTRAFLORAL NECTARIES OF TROPICAL SPECIES IN A MEXICAN RAIN FOREST
}

\author{
ESTRUTURA E HISTOLOGIA DOS NECTARIOS EXTRAFLORAIS DE ESPECIES \\ EM UMA FLORESTA TROPICAL NO MÉXICO
}

\section{Dulce RODRÍGUEZ-MORALES ${ }^{1}$; Armando AGUIRRE ${ }^{2}$; Rosamond COATES ${ }^{3}$; Cecilia DÍAZ-CASTELAZO²; Guillermo ANGELES ${ }^{4}$}

1. Doutoranda em Neuroetologia, Instituto de Neuroetología, Universidad Veracruzana, Xalapa, Veracruz, México; 2. Pesquisador, Doutor, Instituto de Ecología, A.C., Red de Interacciones Multitróficas, Xalapa, Veracruz, México. armando.aguirre@inecol.mx; 3. Pesquisadora do Estación de Biología Tropical "Los Tuxtlas", Instituto de Biología-UNAM, Veracruz, México; 4. Pesquisador, Doutor, Instituto de Ecología, A.C. Red de Ecología Funcional, Xalapa, Veracruz 91070 México.

\begin{abstract}
Although there is a large diversity of plant species with extrafloral nectaries, histological detail of these glands is poorly documented in tropical rain forest species. We characterized extrafloral nectaries using digital photographs, scanning electron microscopy and histological methods for eight plant species belonging to the Costaceae, Euphorbiaceae, Malvaceae and Salicaceae. To our knowledge, there are no previous reports on the structure of extrafloral nectaries for these species. Croton species exhibited reddish extrafloral nectaries on the petioles, surrounded by starshaped trichomes. Cnidoscolus multilobus and Omphalea oleifera showed green, elevated, extrafloral nectaries at the peduncle; $C$. multilobus showed abundant secretory tissue; O. oleifera revealed numerous cells with calcium oxalate crystals. Heliocarpus species showed extrafloral nectaries distributed at the base of the blade and possesses glands in the center of the extrafloral nectary surrounded by a series of parenchymatic cells. Pleuranthodendron lindenii has two extrafloral nectaries at the base of the leaves. Costus scaber has a hollow-type extrafloral nectary on the red-colored bracts of the inflorescence; nectar cavity is found in the center area of each bracts located on a yellow line. The extrafloral nectaries described in this study exhibited different morphologies and histological structures involved in the secretion of extrafloral nectar that could be related to biotic defenses, primarily by attracting ants.
\end{abstract}

KEYWORDS: Elevated extrafloral nectaries. Anatomy. Los Tuxtlas. Secretory tissue.

\section{INTRODUCTION}

Extrafloral nectaries (EFNs) are nectar secretory structures, which are not related to the pollination processes (HEIL, 2011). EFNs are very diverse morphologically and include glandular structures that differ in their location, size and form (BENTLEY, 1977; ELIAS, 1983; DÍAZCASTELAZO et al., 2005). They can be found on almost every above-ground plant part, including leaves, petioles, bud bracts, stipules, stems, cotyledons, fruits, and on the exterior of sepals (ELIAS, 1983). Also, they exhibit a great variety of forms: single-celled, nectar-secreting hairs, amorphous glandular tissue, complex raised cups and shallow bowl-like depressions, which may be highly vascularized or completely lacking vascularization (ELIAS, 1983).

The presence of EFNs in plants has been reported world wide for approximately $25 \%$ of the angiosperms (ZIMMERMAN, 1932; ELIAS, 1983; KOPTUR, 1992). Other estimations yield 3,941 species in 745 genera and 108 families (WEBER; KEELER, 2013). The majority of plant species with EFNs are found in the Asteraceae, Euphorbiaceae, Fabaceae, Lamiaceae, Melastomataceae,
Orchidaceae and Rubiaceae (MELO et al., 2010; KELLER, 2011; COUTINHO et al., 2012). The top three families with the highest number of species documented with EFNs are Fabaceae (1,069 species, $5 \%$ in Fabales), Passifloraceae (935 species, $47 \%$ in Malpighiales), and Malvaceae (293 species, 7\% in Malvaceae); other families with high number of species with EFNs are Euphorbiaceae (286 species, $5 \%)$ and Bignoniaceae (140 species, 17\%) (WEBER; KEELER, 2013). On the other hand, the genera with the most EFN-bearing species are Passiflora (322 species), Inga (294 species), and Acacia (204 species) (WEBER; KEELER, 2013).

Although a large diversity of species bearing EFNs has been reported, information on anatomical aspects (morphology and types of EFNs) and histological studies is poorly known and is fragmented among the diverse taxa. Our study focuses on describing, for the first time, the morphological and anatomical characteristics of EFNs in eight species of four tropical plant families: Costaceae, Euphorbiaceae, Malvaceae and Salicaceae. These species are common plants, part of the typical landscape of the Los Tuxtlas region, including shade tolerant species (mature forest) and pioneer species (secondary growth) (IBARRA- 
MANRÍQUEZ et al., 1997). There are several studies related to EFNs for Euphorbiaceae (DAVE AND PATEL, 1975; FIALA; MASCHWITZ, 1991; FIALA and LINSENMAIER, 1995, FREITAS et al., 2001; DÍAZ-CASTELAZO et al., 2005, COUTHINO et al., 2010), as well as Malvaceae (MACHADO et al., 2008; 2009). However, for Costaceae (SCHEMSKE, 1982) and Salicaceae (THADEO et al., 2008) the information is very scarce. Regardless of the thematic variety and the number of studies, only a few studies integrally cover aspects related to morphology and histology. The aim of this study is to describe the morphological and anatomical features of the EFNs for eight tropical tree species. Although these species may belong to taxonomically non-related groups, they have very conspicuous EFNs and are submitted to similar ecological conditions and possibly to similar selective pressures (i.e. nectarforaging arthropods, herbivory, etc.). Moreover, it is important to understand ecological aspects derived from nectar secretion through the structural and anatomical traits of these glands (i.e. vascularization, support tissue), since these features may determine nectar quality, secretory rates and attraction by nectar-foraging ants. These features may, at specific contexts, provide anti-herbivory benefits and influence the arthropod community associated to these EFN-bearing plant species.

\section{MATERIAL AND METHODS}

\section{Study site}

The study was carried out within the natural forest reserve of the Los Tuxtlas Tropical Biology Field Station of the Institute of Biology, Universidad Nacional Autónoma de México (UNAM), in southeastern Mexico (18 35.077' N; $95^{\circ} 4.442^{\prime} \mathrm{W}$; altitudinal range $120-530 \mathrm{~m}$ a.s.l.) (GONZÁLEZ-SORIANO et al., 1997; GARCÍAAGUIRRE et al., 2010). The Los Tuxtlas region is the northernmost limit of the tropical rain forest in the Neotropics (DIRZO; MIRANDA, 1991). The flora within the UNAM reserve is composed of ca. 1,000 species of vascular plants (545 genera and 137 families), of which 278 species are woody tree species that represent 31.7 percent of the flora within the reserve (IBARRA-MANRÍQUEZ et al., 1997). The predominant vegetation type is evergreen rain forest in the lowlands, with variations along the regional altitudinal gradient $(0-1,680 \mathrm{~m}$ a.s.1.), including cloud forest and mixed forests at higher elevations (GARCÍA-AGUIRRE et al., 2010). The flora is mainly composed of plants of Neotropical origin, but higher elevation sites include combinations of Neotropical and Neartic taxa (IBARRA-MANRÍQUEZ et al., 1997).

A previous pioneer study in the Los Tuxtlas region reported only five species of plants with EFNs (IBARRA-MANRÍQUEZ; DIRZO, 1990). In a more recent study, Aguirre et al. (2013) documented 50 species with EFNs (16 families, 31 genera). Families with the highest number of species with EFNs were Fabaceae and Euphorbiaceae, which accounted for $52 \%$ of species with EFNs in Los Tuxtlas. The remaining $48 \%$ included plants in 14 families. That study reported six different morphological types of EFNs.

\section{Study species}

Study plants comprise eight tropical species belonging to four families: I) Euphorbiaceae (four species): a) Croton pyramidalis Donn.Sm. a pioneer tree, with two reddish EFNs at the base of the leaf (Figure 1A); b); Croton draco Schltdl. and Cham. a pioneer tree, with 2-4 reddish EFNs at the base of the leaf (Figure 1F); c) Cnidoscolus multilobosus (Pax) I.M. Johnst. a shrub, with 2-3 EFNs, commonly in pairs found at the base of the leaf blade (Figure 1K), and d) Omphalea oleifera Hemsl. a canopy tree, which presents 2-3 small EFNs on the underside of the leaf at the base of the peduncle (Figure 1P); II) Malvaceae (two pioneer tree species): Heliocarpus donnellsmithii Rose and Heliocarpus appendiculatus Turcz. In both species the EFNs are located at the base of the leaf margin (Figure 2A); III) Salicaceae (one tree species), Pleuranthodendron lindenii (Turcz.) Sleumer, which has two EFNs at the base of the leaf blade (Figure 2F); and IV) Costaceae (one perennial herb) Costus scaber Ruiz and Pav. with EFNs arranged along the bracts of the inflorescences in variable numbers and sizes (Figure 2P). All plant material was collected in April of 2012. Voucher specimens are deposited in the herbarium of the Los Tuxtlas Tropical Biology Field Station, UNAM.

\section{Histological methods}

Vegetative parts used for histological studies were fixed in FAA for at least 24 hours. Samples were dehydrated initially in an ethanol solution series $(30,50$, and $70 \%)$ and then, in a gradual tertiary butanol series $(30,50,70,96$, and $100 \%$ ), and finally embedded in paraffin (VILLAMIL et al., 2013). Considering the EFNs as a unit, we obtained $12-\mu \mathrm{m}$-thick transverse sections in secretory cells area and longitudinal sections in the central area of the EFNs in each sample. Rotary microtome (LEICA) was used, and the sections 
were stained with safranin and fast green, followed by clove oil to fix the stain (RUZIN, 1999).

\section{Images of the extrafloral nectaries (EFNs)}

Digital photographs were obtained for EFNs using a Nikon Camera D50 (SIGMA DG; macro lens of $70 \mathrm{~mm}, 1: 2.8$ ). Sample preparation for scanning electron microscopy consisted of fixing samples in formalin -acetic acid- ethanol 70\% (FAA). Samples were washed with water for two hours, and then dehydrated in an ethanol solution series $(30,50,70,96$, and 100\%). Samples were critically-point dried and then sputter-coated with gold-palladium. Observations were performed using a JEOL JSM 5600LV scanning electron microscope $(25 \mathrm{kV})$.

\section{RESULTS}

\section{a) Euphorbiaceae}

In the species studied in Los Tuxtlas region we found diverse morphologies and types of EFNs. In the trees of Euphorbiaceae EFNs were located at the distal end of the petiole, close to the base of the blade (Figures 1A, F, K, P). Details of each species are as following: i) Croton pyramidalis (Figure 1A) presents a pair of red dish-like EFNs on each side of the petiole which are surrounded by numerous starshaped trichomes, the surface of the EFN is wrinkled (Figures 1B, C). Several vascular elements apparently related to the secretion of extrafloral nectar and a dense parenchyma were observed (Figure 1D). A large number of calcium oxalate crystals were observed in the parenchyma (Figures 1D, E). ii) Croton draco generally has a pair of reddish, elevated EFNs at the extreme portion of the gland, but may occasionally present three EFNs (Figure 1F). Surrounding the EFNs we observed a large number stellate trichomes (star-shaped trichomes), which delimit the nectar cavity (Figures $1 \mathrm{G}, \mathrm{H})$. In longitudinal sections the cuticle (ct), the secretory tissue (st) and the vascular elements (vt) can be observed (Figure 1I).

In the cross section we showed part of the secretory tissue (st), that was delimited by the cuticle in the edge (Figure 1J). iii) Cnidoscolus multilobus has 2-3 elevated EFNs at the base of the leaf (Figure 1K). A nectar cavity can be observed (Figures 1L, M); a secretory tissue (st) was located just below the cuticle (ct) (Figures 1N-O); and iv). Omphalea oleifera presents 2-3 elevated and elongated EFNs on opposite sides, at the base of the leaf, in the distal portion of the peduncle (Figure $1 \mathrm{P}$ ). The nectar cavity (ca) presented well-defined margins (Figures 1Q, R). The transverse and longitudinal sections revealed numerous cells with calcium oxalate crystals (d), as well as parenchyma (tp) and secretory tissue (st) grouped just below the cuticle (ct) (Figures 1S, T).

\section{b) Malvaceae}

In this family the following EFNs were documented: i) Heliocarpus donnell-smithii has between 6-22 EFNs along the base of the leaf, and projections at the base of the leaf blade are evident (Figure 2A). The EFNs were surrounded by unicellular trichomes and a nectar cavity was found towards the central portion of the gland (Figure 2B). Numerous capitated trichomes could be seen in the interior of the nectar cavity (Figure 2C). The margins of the cavity were defined by numerous enclosed secretory cells. The secretory tissue (st) was denser than the surrounding parenchyma (tp) (Figure 2D). Transverse section through the secretory tissue (st) shows several capitate trichomes, more abundant towards the cavity (ca), below the cuticle (ct) (Figure 2E). These trichomes showed a few cells involved in nectar secretion. ii) Heliocarpus appendiculatus presents 4-7 very distinct elevated EFNs at the base of the leaf, on the foliar appendages (Figure 2F). The margins (mc) surrounding the cavity (ca) were well developed (Figures 2G, H). Longitudinal section through the base of the cavity showed a group of secretory tissue (st) at certain distance from the cuticle (ct) (Figures 2I, J).

\section{c) Salicaceae}

Pleuranthodendron lindenii presents two separate, elevated EFNs at the base of the leaf (Figure 2K). These EFNs shown here have slightly elevated margins (mc) surrounding the cavity (ca) (Figures 2L, M). The cross section through the base of the blade, shows accumulation of secretory tissue (st) close to the adaxial surface and below unicellular trichomes (Figures 2N, O).

\section{d) Costaceae}

Costus scaber presents hollow EFNs on the red-colored bracts of the inflorescences, the EFNs are easily detected due to the presence of a yellowish stripe on the bract (Figure 2P). The number of EFNs is variable and seems to depend on the size of the inflorescence. We observed that the more active EFNs were found on the apical part of the inflorescence where the bracts were immature (Figure 2P). The nectar cavity, as well as the marginal cavity, was located in the central area of the bracts (Figures 2Q, R). Transverse section of a bract, showed secretory tissue (st) just below the 
cuticle (ct) at the adaxial surface, where several vascular strands (vt) were seen, together with a few interspersed (darker) secretory cells (st) (Figure 2S). In the longitudinal section of a bract, showing several vascular strands in red color (vt) and nonsecretory parenchyma cells (tp) (Figure 2T).

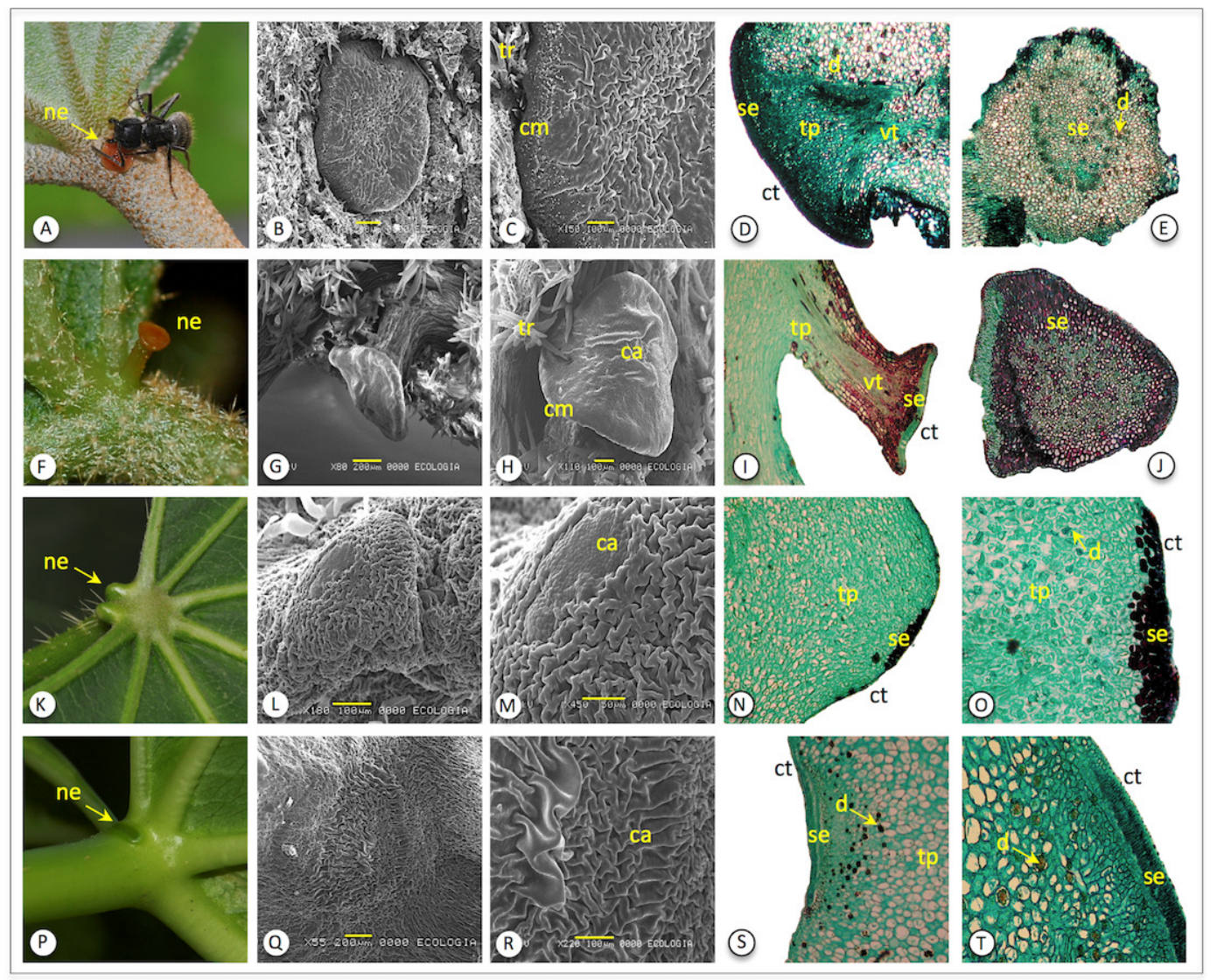

Figure 1. Details of the structure of the extrafloral nectaries in four species of Euphorbiaceae. (A) Elevated EFN in Croton pyramidalis with Dolichoderus bispinosus ant foraging nectar; (B, C) scanning electron micrograph of EFN and details of nectar cavity surface; (D, E) longitudinal and transverse sections of EFNs showing cuticle, secretory epidermis and calcium oxalate crystals. (F) Croton draco with elevated type EFNs; $(\mathrm{G}, \mathrm{H})$ scanning electron micrograph showing numerous trichomes around of EFNs; (I, J) longitudinal and transverse sections showing dense parenchyma and vascular elements. (K) Pairs of elevated EFNs in Cnidoscolus multilobus; (L, M) Scanning electron micrograph of the nectar cavity; $(\mathrm{N}, \mathrm{O})$ longitudinal and transverse sections showing secretory and parenchyma cells. (P) Elevated EFNs at the petiole base in Omphalea oleifera; $(\mathrm{Q}, \mathrm{R})$ scanning electron micrograph showing details of the nectar cavity; (S) longitudinal section showing cuticle, secretory epidermis and tight parenchyma; $(\mathrm{T})$ transversal section with calcium oxalate crystals. Abbreviations: (ct) cuticle; (ca) cavity; (se) secretory epidermis; (tp) tight parenchyma; (d) calcium oxalate crystals; (vt) vascular elements; (tr) simple unicellular trichome; (cm) marginal cavity; (ne) extrafloral nectary. Scale bars: $B=200 \mu \mathrm{m} ; \mathrm{C}=100 \mu \mathrm{m} ; \mathrm{G}=200 \mu \mathrm{m} ; \mathrm{H}=100 \mu \mathrm{m} ; \mathrm{L}=100 \mu \mathrm{m} ; \mathrm{M}$ $=50 \mu \mathrm{m} ; \mathrm{Q}=200 \mu \mathrm{m} ; \mathrm{R}=100 \mu \mathrm{m} ; \mathrm{D}, \mathrm{E}, \mathrm{I}, \mathrm{J}, \mathrm{N}, \mathrm{O}, \mathrm{S}, \mathrm{T}:$ Scale bar $=200 \mu \mathrm{m}$ 


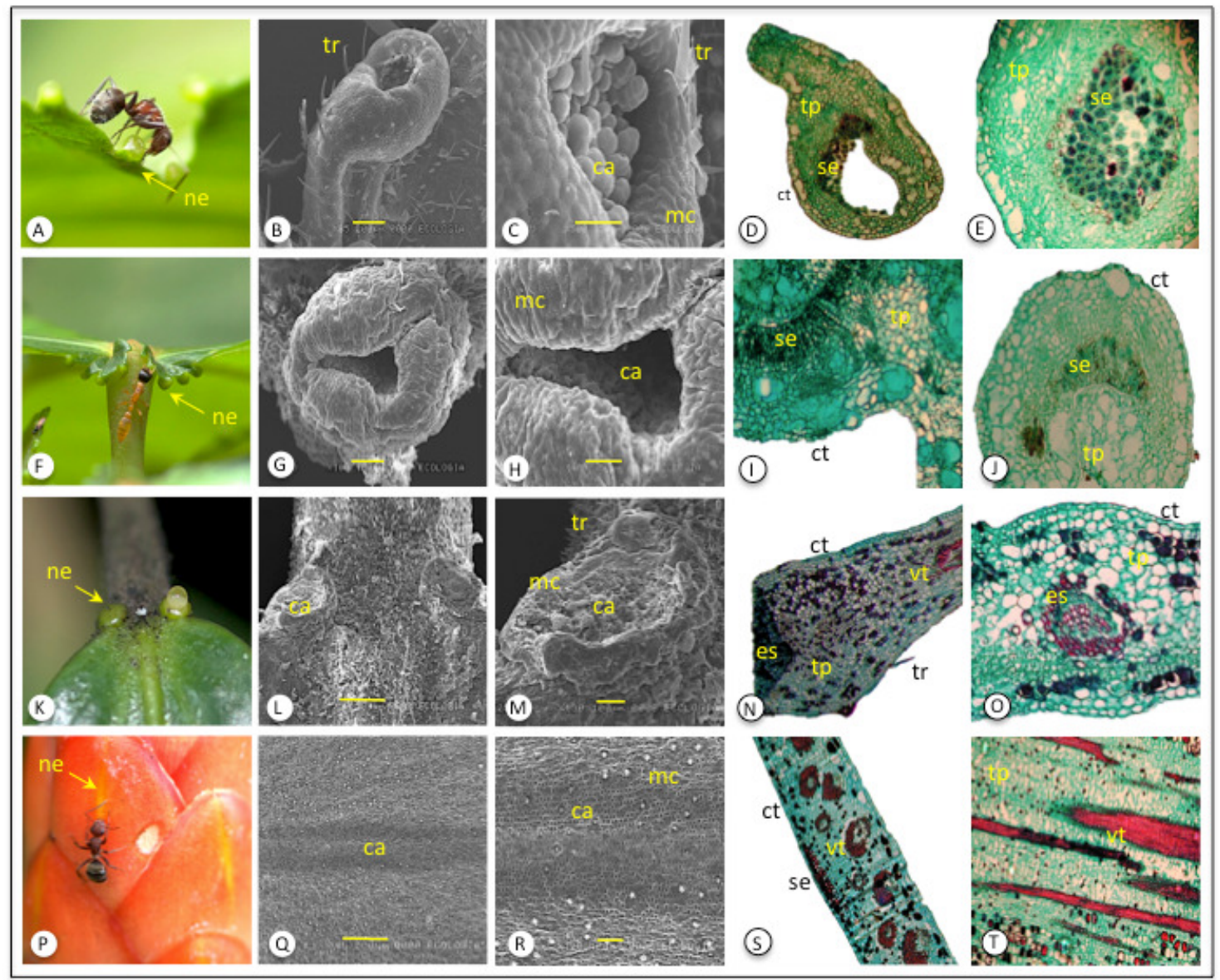

Figure 2. Morphology and histology of EFNs. (A) Elevated EFN in Heliocarpus donnell-smithii with an ant (Camponous planatus) on EFN; (B) scanning electron micrograph of EFN surrounded by numerous trichomes ; (C) EFN cavity showing numerous secretory trichomes; (D) longitudinal and (E) transverse sections of EFN showing the secretory epidermis. (F) Elevated EFN in H. appendiculatus with foraging ant (Pseudomyrmex salvini); (G, H) scanning electron micrograph showing cavity and marginal cavity of EFN; (I, J) longitudinal and transverse sections showing dense parenchyma and secretory elements. (K) Pairs of elevated EFNs in Pleuranthodendron lindenii with a drop of nectar; (L, M) scanning electron micrograph of the surface of nectar cavity and some surrounding trichomes; ( $\mathrm{N}, \mathrm{O})$ longitudinal and transverse sections showing vascular traces and tight parenchyma tissue. (P) Hollow type EFN in Costus scaber with ant (Camponotus planatus). (Q, R) Scanning electron micrograph showing details of the nectar cavity; (S) longitudinal section showing cuticle, secretory epidermis and vascular traces; $(\mathrm{T})$ transverse section with vascular traces and tight parenchyma. In the transverse and longitudinal sections the yellow line represent $0.2 \mathrm{~mm}$. Abbreviations: (ct) cuticle; (ca) cavity; (st) secretory tissue; (tp) tight parenchyma; (vt) vascular elements; (tr) simple unicellular trichome; (cm) marginal cavity; (ne) EFN. Scale bars: B $=200 \mu \mathrm{m}$; $\mathrm{C}=50 \mu \mathrm{m} ; \mathrm{G}=100 \mu \mathrm{m} ; \mathrm{H}=50 \mu \mathrm{m} ; \mathrm{L}=50 \mu \mathrm{m} ; \mathrm{M}=100 \mu \mathrm{m} ; \mathrm{Q}=500 \mu \mathrm{m} ; \mathrm{R}=100 \mu \mathrm{m} ; \mathrm{D}, \mathrm{E}, \mathrm{I}, \mathrm{J}$, $\mathrm{N}, \mathrm{O}, \mathrm{S}, \mathrm{T}$ : Scale bar $=200 \mu \mathrm{m}$.

\section{DISCUSSION}

Although anatomical and morphological descriptions of EFNs have already been done for several species of Euphorbiaceae (DAVE; PATEL, 1975; FIALA; MASCHWITZ, 1991; FIALA; LINSENMAIER, 1995; FREITAS et al., 2001; DÍAZ-CASTELAZO et al., 2005; COUTHINO et al., 2010) neither of the two species reported herein have been previously described. In the Malaysia Peninsula the genus Croton is reported to have nine species with EFNs. In Croton species, the EFN glands occur in pairs on the undersurface of the leaves near the stalk insertion (FIALA; MASCHWITZ, 1991). Our findings for $C$. pyramidalis and $C$. draco showed very similar 
structures and locations of the EFNs and surounding stellates trichomes, that are characterized by having several elongations arising from a common base (SIMPSON, 2006). Furthermore, we found that $C$. draco occasionally presented more than two EFNs in contrast with other species of the same genus (FIALA; MASCHWITZ, 1991; FREITAS et al., 2001), whereas $C$. pyramidalis showed only a pair of EFNs. It is important to highlight that EFNs in $C$. pyramidalis exhibited a peculiar elongated form with a dish-like red tip. It is a very peculiar morphology and coloration of an EFN; we have only seen similar appearance in a few Fabaceae (e.g. Chamaecrista) and in Heteropterys laurifolia (Malpighiaceae) (A. AGUIRRE, obs. pers.). Omphalea oleifera and Cnidoscolus multilobosus presented 2-3 elevated EFNs at the end of the peduncle and did not possess capitate trichomes or vascular system, as observed for other plant families, such as Malvaceae (ROCHA; MACHADO 2009). The cells below the cuticle have secretory activity, thus the cuticle itself seem to play the role of extrafloral nectary secretion (NEPI, 2007). In the case of $O$. oleifera, oxalate crystals occur in the parenchyma cells. This feature has also been reported for nectaries on male flowers of $C$. sarcopetalus (FREITAS et al., 2001).

Studies describing the anatomy and histological details of EFNs for the family Malvaceae are scarce. In this family, EFNs occur in the form of striations, chambers or depressions coated with multicellular secretory trichomes (SAWIDIS et al., 1987a, b; 1989; SAWIDIS, 1991; 1998; VOGEL, 2000). Regardless the fact that species of the Malvaceae are well represented in tropical ecosystems, the secretory structures and activity of EFNs have been studied in only a few species (ELEFTHERIOU; HALL, 1983; FINDLAY; MERCER, 1971a, b; SANTOS, 1959; SAWIDIS et al., 1987a, b; SAWIDIS, 1991; 1998; REED et al., 1971; REED, 1917; WERGIN et al., 1975). The species studied here, Heliocarpus appendiculatus and $H$. donnell-smithii, showed numerous EFNs distributed on the leaf blade and at the base of the leaf, varying in number (AGUIRRE et al., 2013), and similarly to other Malvaceae species these EFNs are very prominent, and form a protuberance with numerous capitate trichomes in the central part (WERGIN et al., 1975; KRONESTEDT et al., 1986; SAWIDIS et al., $1987 \mathrm{a}, \mathrm{b})$ these glands are constituted by several cells where the extrafloral nectar secretion occurs (MEIRA et al., 2014).

Studies related to morphology and histology of EFNs in the Salicaceae family are reported for
Prockia crucis P. Browne ex L. in Brazil. In Los Tuxtlas, trees of Pleuranthodendron lindenii present two EFNs at the base of the leaves, and similarly with $P$. crucis, have nectariferous parenchyma.

With regard to the Costaceae family, to our knowledge, there are no studies documenting the fine details related to the morphology and histology of EFNs. Available information is restricted to plant-ant interactions (SCHEMSKE, 1982; BLÜTHGEN et al., 2000) that have addressed the functional ecology of their EFNs in relation to ants foraging on nectar. However, there is a lack of information on histology or detailed morphology of the glands, which could set lights into the production of extrafloral nectar and its implications (physiological, ecological, or taxonomical) for specific plant genera.

Our studied species have parenchymatic EFNs with parenchyma that give support and structure, also a cuticle to avoid tissue desiccation. The nectar accumulates in a subcuticular space, and exudes by microchannels, as decribed by NEPI (2007). Furthermore, they present a secretory epidermis that, in some cases, such as in Heliocarpus appendiculatus and $H$. donnell-smithii, have specialized cells, such as capitate trichomes, for nectar secretion. Three of the studied species $C$. draco, $C$. multilobus and $O$. oleifera have calcium oxalate crystals, that can be involved in deterrence of herbivores, and may be an alternative chemical mechanism of defense (VILLAMIL et al., 2013).

Our study provides important, original information on the morphology and histology of EFNs for eight tropical tree species. In spite of the large diversity of species bearing EFNs in the families herein studied (OLIVEIRA; LEITAOFILHO, 1987; SCHUPP; FEENER, 1991; FIALA; LINSENMAIR, 1995; BLÜTHGEN; REIFENRATH, 2003; DÍAZ-CASTELAZO et al., 2005; MACHADO et al., 2008; AGUIRRE et al., 2013), we reported several features that have not been described before, maybe because of difficulties in detection with superficial observation. For example, the EFNs on the bracts of Costus scaber, which appear as faint, yellow strips on the adaxial surface of the bract. Our study characterizes, for the first time, the anatomical and histological details of extrafloral nectaries in this species. Furthermore, we identified specialized tissues for nectar secretion, such as capitate trichomes. Finally, this study is important to understand implications of the anatomy and location of EFNs on the ecological outcomes of the associated community of nectar-foraging arthropods, like ant-plant interactions, or others consumers like parasitoids, wasps, spiders, mites, 
bugs and small beetles (HEIL, 2015). Since these secretory structures partly determine nectar quality and secretory rates (higher in vascularized glands, than in disperse secretory trichomes) or production of jasmonic acid (DÍAZ-CASTELAZO et al., 2005; HEIL, 2015), they may also promote different antassemblages of species with distinct behaviors and defensive potentials) (DÍAZ-CASTELAZO et al., 2004). In specific cases of constant, intense interaction, ant foragers and its defensive traits may serve as selective agents of EFN anatomy, location and secretory activity.

\section{ACKNOWLEDGEMENTS}

We appreciate the support provided by $\mathrm{T}$. LAES-APONTE with the SEM. We also thank F. ORTEGA-ESCALONA for his many useful suggestions regarding histological techniques. The Los Tuxtlas Tropical Biology Field Station of UNAM provided all necessary facilities for the fieldwork.

RESUMO: Embora exista uma grande diversidade de espécies de plantas com nectários extraflorais, detalhes histológicos destas glândulas ainda é pouco documentado para espécies tropicais. Nós caracterizamos nectários extraflorais usando fotografias digitais, microscopia eletrônica de varredura e métodos histológicos para oito espécies de plantas das famílias Costaceae, Euphorbiaceae, Malvaceae e Salicaceae. Para nosso conhecimento, não há relatos anteriores sobre a estrutura dos nectários extraflorais para as espécies estudadas. Espécies de Croton exibiram nectários extraflorais avermelhadas nos pecíolos, rodeados por tricomas em forma de estrela. Cnidoscolus multilobus e Omphalea oleifera apresentaram nectários extraflorais verdes e elevados nos pedúnculos; C. multilobus apresenta tecido secretor abundante enquanto que $O$. oleifera apresentou numerosas células com cristais de oxalato de cálcio. Espécies de Heliocarpus apresentaram nectários extraflorais distribuídos na base da lâmina e possuíam glândulas no centro do nectário rodeadas por uma série de células de parênquima. Pleuranthodendron lindenii apresentou dois nectários extraflorais na base das folhas. Costus scaber apresenta um nectário extrafloral do tipo oco nas brácteas avermelhadas da inflorescência, e a cavidade do nectário se encontra na área central de cada bráctea localizados em uma linha amarela. Os nectários extraflorais descritos neste estudo apresentaram morfologia e estruturas histológicas diferentes envolvidas na secreção de néctar extrafloral que poderia estar relacionado com defesas bióticas, principalmente atraindo formigas.

PALAVRAS-CHAVE: Nectários extraflorais elevados. Anatomia. Los Tuxtlas. Tecido secretor.

\section{REFERENCES}

AGUIRRE, A.; COATES, R.; CUMPLIDO-BARRAGÁN, G.; CAMPOS-VILLANUEVA, A.; DÍAZCASTELAZO, C. Morphological characterization of extrafloral nectaries and associated ants in tropical vegetation of Los Tuxtlas, Mexico. Flora, v. 208, p. 147-156, 2013.

http://dx.doi.org/10.1016/j.flora.2013.02.008

BENTLEY, B. L. Extrafloral nectaries and protection by pugnacious bodyguards. Annual Review Ecology and Systematics, v. 8, p. 407-427, 1977. http://dx.doi.org/10.1146/annurev.es.08.110177.002203

BLÜTHGEN, N.; REIFENRATH, K. Extrafloral nectaries in an Australian rainforest: structure and distribution. Australian Journal of Botany, v. 51, p. 515-527, 2003. http://dx.doi.org/10.1071/BT02108

BLÜTHGEN, N.; VERHAAGH, M.; GOITÍA, W.; JAFFÉ, K.; MORAWETZ, W.; BARTHLOTT, W. How plants shape the ant community in the Amazonian rainforest canopy: the key role of extrafloral nectaries and homopteran honeydew. Oecologia, v. 125, p. 229-240, 2000. http://dx.doi.org/10.1007/s004420000449

COUTINHO, Í. A. C.; FRANCINO, D. M. T.; AZEVEDO, A. A.; MEIRA, R. M. SA. Anatomy of the extrafloral nectaries in species of Chamaecrista section Absus subsection Baseophyllum (Leguminosae, Caesalpinioideae). Flora, v. 207, p. 427-435, 2012. http://dx.doi.org/10.1016/j.flora.2012.03.007

COUTINHO, Í. A. C.; VALENTE, V. M. M.; MEIRA, R. M. SA. Ontogenetic, anatomical and histochemical study of the extrafloral nectaries of Sapium biglandulosum (Euphorbiaceae). Australian Journal of Botany, v. 58, p. 224-232, 2010. http://dx.doi.org/10.1071/BT09200 
DAVE, Y. S.; PATEL, N. D. A Development Study of Extrafloral Nectaries in Slipper Spurge (Pedilanthus tithymaloides, Euphorbiaceae). American Journal of Botany, v. 62, p. 808-812, 1975. http://dx.doi.org/10.2307/2441891

DÍAZ-CASTELAZO, C., RICO-GRAY, V., OLIVEIRA, P.S. CUAUTLE, M.. Extrafloral nectary-mediated ant-plant interactions in the coastal vegetation of Veracruz, Mexico: richness, occurrence, seasonality and ant foraging patterns. Ecoscience, v. 11, p. 472-481, 2004.

DÍAZ-CASTELAZO, C.; RICO-GRAY, V.; ORTEGA, F.; ANGELES, G. Morphological and secretory characterization of extrafloral nectaries in plants of coastal Veracruz, Mexico. Annals of Botany, v. 96, p. 1175-1189, 2005. http://dx.doi.org/10.1093/aob/mci270

DIRZO, R.; MIRANDA, A. El limite boreal de la selva tropical húmeda en el continente Americano: contracción de la vegetación y solución de una controversia. Interciencia, v. 16, p. 240-247, 1991.

ELEFTHERIOU, E. P.; HALL, J. L. The Extrafloral Nectaries of Cotton I. Fine structure of the secretory papillae. Journal of Experimental Botany, v. 34, p. 103-119, 1983. http://dx.doi.org/10.1093/jxb/34.8.1066 http://dx.doi.org/10.1093/jxb/34.2.103

ELIAS, T. S. Extrafloral nectaries: their structure and distribution. In: BENTLEY, B.; ELIAS, T. S. (Ed.). The Biology of Nectaries. Columbia University Press, New York, 1983. p. 174-203.

FIALA, B.; LINSENMAIR, KE. Distribution and abundance of plants with extrafloral nectaries in the woody flora of a lowland primary forest in Malaysia. Biodiversity and Conservation, v. 4, p. 165-182, 1995. http://dx.doi.org/10.1007/BF00137783

FIALA, B.; MASCHWITZ, U. Extrafloral nectaries in the genus Macaranga (Euphorbiaceae) in Malaysia: comparative studies of their possible significance as predispositions for myrmecophytism. Botanical Journal of the Linnean Society, v. 44, p. 287-305, 1991. http://dx.doi.org/10.1111/j.1095-8312.1991.tb00621.x

FINDLAY, N.; MERCER, F. V. Nectar production in Abutilon I. Movement of nectar through the cuticle. Australian Journal of Biological Sciences, v. 24, p. 647-656, 1971a.

FINDLAY, N.; MERCER, F. V. Nectar production in Abutilon II. Submicroscopic structure of the nectary. Australian Journal of Biological Sciences, v. 24, p. 657-664, 1971b.

FREITAS, L.; BERNARDELLO, G.; GALETTO, L.; PAOLI, A. A. Nectaries and reproductive biology of Croton sarcopetalus (Euphorbiaceae). Botanical Journal of the Linnean Society, v. 136, p. 267-277, 2001. http://dx.doi.org/10.1111/j.1095-8339.2001.tb00572.x

GARCÍA-AGUIRRE, M. C.; ÁLVAREZ, R.; DIRZO, R.; ORTÍZ, M. A.; MAH-ENG M. Delineation of biogeomorphic land units across a tropical natural and humanized terrain in Los Tuxtlas, Veracruz, México. Geomorphology, v. 121, p. 245-256, 2010. http://dx.doi.org/10.1016/j.geomorph.2010.04.019

GONZALEZ-SORIANO, E.; DIRZO, R.; VOGT, R. C. Historia Natural de Los Tuxtlas. Universidad Nacional Autónoma de México, México. 1997.

HEIL, M. Nectar: generation, regulation and ecological functions. Trends in plant science, v. 16, p. 191-200, 2011. http://dx.doi.org/10.1016/j.tplants.2011.01.003

HEIL, M. (2015). Extrafloral nectar at the plant-insect interface: A spotlight on chemical ecology, phenotypic plasticity, and food webs. Annual review of entomology, v. 60, p. 213-232, 2015.

http://dx.doi.org/10.1146/annurev-ento-010814-020753 
IBARRA-MANRÍQUEZ, G.; DIRZO, R. Plantas mirmecófilas arbóreas de la Estación de Biología "Los Tuxtlas”, Veracruz, México. Revista de Biología Tropical, v. 38, p. 79-82, 1990.

IBARRA-MANRÍQUEZ, G., MARTÍNEZ-RAMOS, M.; DIRZO, R.; NUÑEZ-FARFAN, J. La vegetación. In: GONZALEZ-SORIANO, E.; DIRZO, R.; VOGT, R. C. (Ed.). Historia Natural de Los Tuxtlas, Universidad Nacional Autónoma de México, México, 1997. pp. 61-85.

KELLER, K. H. World list of angiosperm species with extrafloral nectaries. http://www.biosci.unl.edu/emeriti/keeler/extrafloral/worldlistfamilies. (Accessed 29 June 2011), 2011.

KOPTUR, S. Extrafloral nectary-mediated interactions between insects and plants. In: BERNAYS, E. (Ed.). Insect-Plant Interactions. CRC Press, Boca Raton, USA, 1992. p. 81-129.

KRONESTEDT, E. C., ROBARDS, A. W., STARK, M.; OLSEN, P. Development of trichome in the Abutilon nectary gland. Nordic Journal of Botany, v. 6, p. 627-639, 1986. http://dx.doi.org/10.1111/j.17561051.1986.tb00462.x

MACHADO, S. R.; MORELLATO, L. P. C.; SAJO, M. G.; OLIVEIRA, P. S. Morphological patterns of extrafloral nectaries in woody plant species of the Brazilian Cerrado. Plant Biology, v. 10, p. 660-673, 2008. http://dx.doi.org/10.1111/j.1438-8677.2008.00068.x

ROCHA, J. F., MACHADO, S. R. Anatomy, ultrastructure and secretion of Hibiscus pernambucensis Arruda (Malvaceae) extrafloral nectary. Brazilian Journal of Botany, v. 32, n. 3, p. 489-498, 2009. http://dx.doi.org/10.1590/S0100-84042009000300008

MEIRA, R. M.; FRANCINO, D. M.; ASCENSÃO, L. Oleoresin trichomes of Chamaecrista dentata (Leguminosae): structure, function, and secretory products. International Journal of Plant Sciences, v. 175, p. 336-345, 2014. http://dx.doi.org/10.1086/673538

MELO, Y.; MACHADO, S. R.; ALVES, M. Anatomy of extrafloral nectaries in Fabaceae from dry-seasonal forest in Brazil. Botanical Journal of the Linnean Society, v. 163, p. 87-98, 2010.

http://dx.doi.org/10.1111/j.1095-8339.2010.01047.x

NEPI, M. Nectary structure and ultrastructure. In: NICOLSON S. W., NEPI M. PACINI E. (Ed.). Nectaries and nectar. Springer, Netherlands, 2007, p. 129-166. http://dx.doi.org/10.1007/978-1-4020-5937-7_3

OLIVEIRA, P. S.; LEITAO-FILHO, H. F. Extrafloral nectaries: their taxonomic distribution and abundance in the woody flora of Cerrado vegetation in southeast Brazil. Biotropica, v. 19, p. 140-148, 1987.

http://dx.doi.org/10.2307/2388736

REED, E. L. Leaf nectaries of Gossypium. BOTANICAL GAZETTE, v. 63, p. 229-31, 1917.

REED, M. L.; FINDLAY, N.; MERCER, F. V. Nectar production in Abutilon. IV. Water and solute relations. Australian Journal of the Biological Sciences, v. 24, p. 677-688. http://dx.doi.org/10.1086/332008

RUZIN, S. E. Plant microtechnique and microscopy. Oxford University Press. New York, 1999. 1971 p.

SANTOS, C. F. D. O. Anatomia, dos nectános de algumas espécies da flora apícola. Anais da Escola Superior de Agricultura Luiz de Queiroz, v. 16, p. 87-100, 1959. http://dx.doi.org/10.1590/S007112761959000100006

SAWIDIS, T. A histochemical study of nectaries of Hibiscus rosa-sinensis. Journal of Experimental Botany, v. 42, p. 1477-1485, 1991. http://dx.doi.org/10.1093/jxb/42.11.1477

SAWIDIS, T. The subglandular tissue of Hibiscus rosa-sinensis nectaries. Flora, v. 193, p. 327-335, 1998. 
SAWIDIS, T. H.; ELEFTHERIOU, E. P.; TSEKOS, I. The floral nectaries of Hibiscus rosa-sinensis 1. Development of the secretory hairs. Annals of Botany, v. 59, p. 643-652, 1987a.

SAWIDIS, T. H.; ELEFTHERIOU, E. P.; TSEKOS, I. The floral nectaries of Hibiscus rosa-sinensis L. II. Plasmodesmatal frequencies. Phyton, v. 27, p. 155-164, 1987b.

SCHEMSKE, D. W. Ecological correlates of a neotropical mutualism: ant assemblages at Costus extrafloral nectaries. Ecology, v. 63, p. 932-941, 1982. http://dx.doi.org/10.2307/1937233

SCHUPP, E. W.; FEENER, D. H. Phylogeny, lifeform, and habitat dependence of ant-defended plants in a Panamanian forest. In: HUXLEY, C.R.; CUTLER D. F. (Ed.). Ant-plant interactions. Oxford University, Press: Oxford, , 1991, p. 175-97.

SIMPSON, M.G. Plant morphology. In: Plant Systematics, 2006. Chapter 9, p. 402.

THADEO, M.; CASSINO, M. F.; VITARELli, N. C.; AZEVEDO, A. A.; ARAÚJO, J. M.; VALENTE, V. M.; MEIRA, R. M. Anatomical and histochemical characterization of extrafloral nectaries of Prockia crucis (Salicaceae). American Journal of Botany, v. 95, p. 1515-1522, 2008. http://dx.doi.org/10.3732/ajb.0800120

VILLAMIL, N.; MÁRQUEZ-GUZMÁN, J.; BOEGE, K. Understanding ontogenetic trajectories of indirect defence: ecological and anatomical constraints in the production of extrafloral nectaries. Annals of Botany, v. 112, p. 701-709, 2013. http://dx.doi.org/10.1093/aob/mct005

VOGEL, S. 2000. Floral nectaries of the Malvaceae sensu lato a conspectus. Kurtziana, v. 28, p. 155-171.

WEBER, M. G.; KEELER, K. H. The phylogenetic distribution of extrafloral nectaries in plants. Annals of Botany, v. 111, p. 1251-1261, 2013. http://dx.doi.org/10.1093/aob/mcs225

WERGIN, W. P.; ELMORE, C. D.; HANNY, B. W.; INGBER, B. F. Ultrastructure of the subglandular cells from the foliar nectaries of Cotton in relation to the distribution of plasmodesmata and the symplastic transport of nectar. American Journal of Botany, v. 62, p. 842-849, 1975. http://dx.doi.org/10.2307/2441896

ZIMMERMAN, J. G. Über die extrafloralen nektarien der angiospermen. Beihefte zum Botanischen Zentralblatt, v. 49, p. 99-196, 1932 